\title{
EFFECTS OF FORAGES AND TOTAL MIXED RATIONS PARTICLE SIZE ON PHYSICAL EFFECTIVENESS AND CHEWING ACTIVITY OF LACTATING COWS
}

\author{
B. Stojanović, G. Grubić, N. Đorđević, A. Božičković, A. Ivetić \\ University in Belgrade, Faculty of Agriculture, Nemanjina 6, 11080 Belgrade-Zemun, Republic of \\ Serbia \\ Corresponding author: arcturas@agrif.bg.ac.rs \\ Original scientific paper
}

Abstract: In study are determined effects of four different mean lengths of corn silage, alfalfa haylage and total mixed ration (TMR) for lactating cows on physical effectiveness (pef), physically effective fiber content (peNDF) and total chewing activity. High correlations were found between mean particle length of forages and TMR and their physical effectiveness in lactating cows nutrition as also with physically effective fiber content. Significant effect of ration particle size on stimulating total chewing activity of lactating cows was determined.

Key words: cows, nutrition, physically effective fiber, chewing activity

\section{Introduction}

Using of NDF as chemical indicator of dietary fiber content, does not indicate on more subtle fibers' characteristics such as their importance for the kinetic of digestion and digesta passage, regarding to fibers' physical characteristics. Physical characteristics of fibers affect on animal health, ruminal fermentation and feed conversion efficiency, animal metabolism, milk fat content. Physical characteristics of rations for lactating cows are influenced by dietary forage to concentrate ratio, type of forages and concentrates, and mean particle size of feeds (Stojanović et al. 2009).

Balch (1971) proposed the chewing time per kg of dry matter (DM) as indicator of physical characteristics of forages, which was called index of roughage value. Sudweeks et al. (1981) measured required chewing time for forages and concentrate feeds, and developed indexing system where each feed were given appropriate value regarding to ability for stimulating chewing activity. Using of this index for anticipation of milk fat content, indicated on total chewing time required per $\mathrm{kg}$ of consumed DM as $21.4,32.4$ and $44.8 \mathrm{~min}$. to maintain milk fat content at 3.2, 3.5 and $3.9 \%$. Mertens (1997) developed a system for physically 
effectiveness factor (pef) determination used for calculating of feeds' physically effective fiber-peNDF content.

Traditionally, definition of fiber effectiveness refers to the ability of dietary fibers to maintain an optimal level of milk fat, and to ensure good health of dairy cows (Stojanović et al. 2002). Physically effective fiber-peNDF are associated with the physically characteristics of the fibers (primarily particle size) that affect on total chewing activity (total time of eating and ruminating), as also on two-phase nature of ruminal content (larger floating particles-ruminal mat and liquid content that includes smaller feed particles). Concept of peNDF is a quantification and integration of chemical and physical characteristics of fibers in a single measure or indicator (Stojanović et al. 2008).

System for determination of peNDF based on chemical and physical analyses consists of determination of feed or ration NDF content and portion of feed particles retained on $1.2 \mathrm{~mm}$ sieve (Mertens, 1997). Physically effectiveness factorpef is equivalent to portion of particles larger than $1.2 \mathrm{~mm}$, and content of physically effective fiber-peNDF is calculated by multiplying NDF feed or diet concentration with factor-pef.

Practical system for determination of peNDF intake of lactating cows is based on measuring of mass of feed particles retained by the 19,8 and $1.2 \mathrm{~mm}$ sieves (system of sieves- Penn State Particle Separator - PSPS, Kononoff et al. (2003), and chemical analysis of NDF content of each fraction.

Study was conducted to analyze the effect of different particle size of forages and total mixed rations (TMR) for cows at early lactation, on physically effectiveness of feeds and diets, their physically effective fiber content, as also effect on stimulating of total chewing activity at lactating cows.

\section{Materials and Methods}

Study was conducted at four farms of dairy cows at PKB Corporation Belgrade. During one week, daily in three samples, using system of sieves (Penn State Particle Separator - PSPS) was determined mean particle size and mass of particles' fraction of corn silage, alfalfa haylage and TMR for cows at early lactation.

Two methods were applied for determination of peNDF content (Yang and Beauchemin, 2006): method based on determining a portion of sample DM retained by sieves of PSPS (physically effectiveness factor-pef), and average sample NDF content on DM base; method based on determining a portion of total sample NDF content retained by PSPS-sieves; obtained values are signed as $\mathrm{pNDF}_{3 \mathrm{~s}}$ and peNDF ${ }_{3 s \_n d f}$, respectively.

Average particle size of forages and TMR was determined using Particle Size Analysis method (Heinrichs and Kononoff, 2002). Total chewing activity (TCA, 
intake and ruminating) for forages and TMRs was determined using model of Mertens (1997): TCA ( $\mathrm{min} / \mathrm{kg} \mathrm{DM})=150 \times 0.01 \mathrm{x}$ peNDF (\%).

On the basis of obtained values for dietary DM intake, values for TCA ( $\mathrm{min} /$ day) were determined, for each animal. The study was conducted on total of 403 Holstein cows, at four farms of PKB Corporation Belgrade (99, 109, 84 and 111 cows, respectively). Cows were at early lactation (10-60 days in milking), multiparous (2-5. lactation). Mixed part of ration was formulated to meet requirements for $24 \mathrm{~kg}$ of milk production, with $3.5 \%$ of milk fat and $3.1 \%$ of milk crude protein content. Cows were additionally fed concentrate and extruded soybean, according to milk yield. During the one week, distributed quantity of TMR and orts were recorded daily to calculate feed intake.

Table 1. TMR composition, $\mathrm{kg}$ of $\mathrm{DM}$

\begin{tabular}{|l|c|c|c|c|}
\hline \multirow{2}{*}{ Feeds } & \multicolumn{4}{c|}{ Groups-farms } \\
\cline { 2 - 5 } & I & II & III & IV \\
\hline Corn silage & 5.03 & 5.52 & 4.79 & 5.25 \\
\hline Alfalfa haylage & 0.88 & 0.87 & 0.74 & 0.67 \\
\hline Alfalfa hay & 3.38 & 3.89 & 3.87 & 3.33 \\
\hline Mixture for lactating cows, 18\% CP & 5.34 & 5.18 & 5.34 & 5.73 \\
\hline Extruded soybean meal & 0.92 & 0.74 & 0.90 & 0.73 \\
\hline Beet pulp, dry & 0.38 & 0.27 & 0.36 & 0.47 \\
\hline $\mathrm{NaCl}$ & 0.04 & 0.04 & 0.04 & 0.04 \\
\hline $\mathrm{NaHCO}_{3}$ & 0.07 & 0.07 & 0.07 & 0.07 \\
\hline
\end{tabular}

Tabular values for physically effectiveness of mixture and extruded soybean were taken, 0.3 and 0.4 , respectively (Mertens, 1997).

Chemical analyses of average samples of feeds, TMRs and PSPS-fractions were done at Laboratory of Animal Nutrition, Faculty of Agriculture.

Obtained results were statistically analyzed using computer software STATISTICA v.6 (StatSoft, 2003). Parameters of descriptive statistic and correlations were determined, and ANOVA procedure, and Tuckey Honestly Significant Difference Test, were used to analyze significance of differences $(\mathrm{p}<0.05$ and $\mathrm{p}<0.01)$.

\section{Results and Discussion}

High correlation was found between particle size of forages and TMR. 
Table 2. Average particle size of forages and TMR, mm

\begin{tabular}{|l|c|c|c|c|}
\hline \multicolumn{1}{|c|}{ Item } & I & II & III & IV \\
\hline Corn silage & 9.31 & 8.79 & 8.46 & 7.51 \\
\hline Index & 100 & 94.41 & 90.87 & 80.67 \\
\hline Alfalfa haylage & 8.26 & 7.86 & 7.46 & 7.11 \\
\hline Index & 100 & 95.16 & 90.31 & 86.08 \\
\hline TMR & 8.05 & 7.11 & 6.95 & 5.26 \\
\hline Index & 100 & 88.32 & 86.34 & 65.34 \\
\hline
\end{tabular}

Table 3. Average NDF content of forages, TMR and PSPS-fractions, \% DM

\begin{tabular}{|l|c|c|c|c|}
\hline \multicolumn{1}{|c|}{ Item } & I & II & III & IV \\
\hline Corn silage & 47.03 & 42.34 & 48.34 & 46.45 \\
\hline Fractions of particles & & & & \\
\hline$>19.0 \mathrm{~mm}$ & 60.15 & 69.93 & 61.31 & 62.23 \\
\hline $19.0-8.0 \mathrm{~mm}$ & 48.00 & 56.75 & 45.66 & 46.53 \\
\hline $8.0-1.2 \mathrm{~mm}$ & 44.43 & 42.19 & 43.38 & 43.77 \\
\hline$<1.2 \mathrm{~mm}$ & 29.77 & 28.86 & 27.33 & 28.02 \\
\hline Alfalfa haylage & 45.83 & 46.21 & 43.63 & 43.56 \\
\hline Fractions of particles & & & & \\
\hline$>19.0 \mathrm{~mm}$ & 53.99 & 50.27 & 57.02 & 51.40 \\
\hline $19.0-8.0 \mathrm{~mm}$ & 50.15 & 48.38 & 50.01 & 47.55 \\
\hline $8.0-1.2 \mathrm{~mm}$ & 43.00 & 42.32 & 44.36 & 42.51 \\
\hline$<1.18 \mathrm{~mm}$ & 35.14 & 39.35 & 33.22 & 37.38 \\
\hline TMR & 35.13 & 35.06 & 33.94 & 36.27 \\
\hline Fractions of particles & & & & \\
\hline$>19.0 \mathrm{~mm}$ & 57.07 & 53.33 & 60.69 & 57.42 \\
\hline $19.0-8.0 \mathrm{~mm}$ & 37.38 & 35.72 & 35.09 & 38.28 \\
\hline $8.0-1.2 \mathrm{~mm}$ & 36.59 & 33.68 & 36.87 & 33.38 \\
\hline$<1.2 \mathrm{~mm}$ & 24.78 & 27.14 & 24.86 & 21.78 \\
\hline
\end{tabular}

Obtained values for physically effective fiber content of TMR indicate that lowering average particle size of forages decreases peNDF content, and decreases physical effectiveness of ration. Correlation between TMR average particle size and concentration of peNDF ${ }_{3 \mathrm{~s}}$ was $\mathrm{r}=0.97$, whereas for $\mathrm{peNDF}_{3 \mathrm{~s} \text {-ndf }}$ was $\mathrm{r}=0.73$.

Determined values for corn silage, indicate that correlation between particle size and peNDF content was even low negative $r=-0.06$ for $\mathrm{peNDF}_{3 \mathrm{~s}}$, and $\mathrm{r}=-0.09$ for peNDF ${ }_{3 s-n d f}$ content. This is a result of different NDF concentration of corn silages from different farms (42.34-48.34\% DM). Obtained values for effect of alfalfa haylage average particle size on physically effective fiber content were $\mathrm{r}=0.72$ for $\mathrm{peNDF}_{3 \mathrm{~s}}$, and $\mathrm{r}=0.88$ for $\mathrm{peNDF}_{3 \mathrm{~s} \text {-ndf. }}$ 
Table 4. Physically effectiveness factor and peNDF content (\%DM) of forages and TMR

\begin{tabular}{|c|c|c|c|c|}
\hline Item & $\mathrm{I}$ & II & III & IV \\
\hline \multicolumn{5}{|l|}{ Corn silage } \\
\hline pef & 0.98 & 0.98 & 0.97 & 0.97 \\
\hline peNDF $_{3 \mathrm{~s}}$ & 46.14 & 41.62 & 47.08 & 45.20 \\
\hline peNDF $_{3 s-n d f}$ & 46.46 & 41.95 & 47.59 & 45.68 \\
\hline Average & 46.30 & 41.79 & 47.34 & 45.44 \\
\hline \multicolumn{5}{|l|}{ Alfalfa haylage } \\
\hline pef & 0.90 & 0.91 & 0.89 & 0.91 \\
\hline peNDF $_{3 \mathrm{~s}}$ & 41.38 & 42.00 & 38.74 & 39.73 \\
\hline peNDF $_{3 s-n d f}$ & 42.53 & 42.60 & 40.22 & 40.38 \\
\hline Average & 41.96 & 42.3 & 39.48 & 40.06 \\
\hline \multicolumn{5}{|l|}{ TMR } \\
\hline pef & 0.96 & 0.93 & 0.93 & 0.84 \\
\hline $\mathrm{peNDF}_{3 \mathrm{~s}}$ & 33.55 & 32.54 & 31.63 & 30.39 \\
\hline peNDF $_{3 s-n d f}$ & 34.14 & 33.14 & 32.36 & 32.58 \\
\hline Average & 33.85 & 32.84 & 32.0 & 31.49 \\
\hline
\end{tabular}

Determined values for peNDF content of forages and TMR were slightly higher, when second method was used.

Obtained results are consistent with earlier studies. Values for TMR physically effectiveness factors (pef) were within a narrow interval 0.93-0.94, whereas peNDF content ranged between 28.6-34.0\%, and were not obtained differences in pef and peNDF contents, between rations based on alfalfa haylage with different chopping length (7.9 and $19.1 \mathrm{~mm}$ ), (Yang and Beauchemin, 2007). Yang and Beauchemin (2006) compared results of measuring the distribution of PSPSfractions of TMR particles (three different average particle size), and found values for pef were within the interval 0.89-0.85.

Table 5. Average values for total chewing activity of lactating cows

\begin{tabular}{|l|c|c|c|c|}
\hline \multicolumn{1}{|c|}{ Feeds } & I & II & III & IV \\
\hline \multicolumn{4}{|c|}{ min/kg of consumed DM } \\
\hline Corn silage & 69.45 & 62.69 & 71.01 & 68.16 \\
\hline Index & 100.0 & 90.27 & 102.25 & 98.14 \\
\hline Alfalfa haylage & 62.94 & 63.45 & 59.22 & 60.09 \\
\hline Index & 100.0 & 100.81 & 94.09 & 95.47 \\
\hline TMR & 39.70 & 38.96 & 37.78 & 37.19 \\
\hline Index & 100.0 & 98.14 & 95.16 & 93.68 \\
\hline \multicolumn{5}{|c|}{ min/day } \\
\hline TMR & $864.27^{\text {a }}$ & $867.10^{\text {ab }}$ & $825.83^{\mathrm{c}}$ & $822.84^{\text {d }}$ \\
\hline Index & 100.0 & 100.33 & 95.55 & 95.21 \\
\hline
\end{tabular}

a,b,c,d Means in the same row with different superscripts differ $(\mathrm{p}<0.01)$

Obtained results indicate on high correlation between chewing activity and particle size of alfalfa haylage $(\mathrm{r}=0.80)$. High correlation is determined between 
TMR particle size and total chewing activity of lactating cows $(r=0.90)$ expressed as $\mathrm{min} / \mathrm{kg}$ of consumed DM, and slightly lower $\mathrm{r}=0.75$ when expressed as min/day. There was no correlation between the average particle size of corn silage and total chewing activity of cows $(\mathrm{r}=-0.08)$, which is likely due to different content of peNDF and NDF of analyzed silages.

There was a significant effect $(\mathrm{p}<0.01)$ of decreasing TMR particle size on reduction of total chewing activity (min/day). The highest value for total chewing activity was determined at cows fed ration with the largest average particle size (8.05 mm, I-group), and the least at cows at the fourth group (particle size 5.26 $\mathrm{mm})$.

Determined values for total chewing activity are consistent with earlier researching. Decreasing of forages' particle size $(5.3$ and $2.7 \mathrm{~mm}$ for alfalfa haylage, and 5.6 and $2.8 \mathrm{~mm}$ for corn silage), reduced chewing activity for consuming of ration ( 4.2 to $3.6 \mathrm{~h} /$ day, and from 11.0 to $9.9 \mathrm{~min} / \mathrm{kg} \mathrm{DM}$ ), the chewing time for ruminating was also reduced $(7.3$ to $5.7 \mathrm{~h} /$ day, and 19.2 to 16.3 $\mathrm{min} / \mathrm{kg} \mathrm{DM}$ ), (Krause and Combs, 2003). Reducing of cutting length of alfalfa haylage (22.3 to $4.8 \mathrm{~mm}$ ) in ration for Holstein cows at early lactation, decreases total chewing time from 776.7 to $723.4 \mathrm{~min} /$ day, from 37.9 to $31.2 \mathrm{~min} / \mathrm{kg} \mathrm{DM}$, as also from 120.8 to $99.7 \mathrm{~min} / \mathrm{kg}$ of consumed NDF (Kononoff and Heinrichs, 2003). Total chewing time and ruminating time are in positive correlation with forages' content of peNDF and NDF (Zebeli et al. 2006). Higher TMR concentration of peNDF increases chewing activity, as also salivation, and prevents decreasing of ruminal $\mathrm{pH}$, due to buffering effect of saliva and neutralization of large quantity of acids formed due to fermentation.

\section{Conclusion}

Using of PSPS-sieves system is an efficient and practical method for determination of physical effectiveness of forages and total mixed rations. It was obtained a significant correlation and effect of alfalfa haylage and TMR particle size on physically effective fiber content and total chewing activity of lactating cows. Reducing TMR average particle size decreases total chewing activity of lactating cows. There was not determined correlation between particle size of corn silage and physically effective fiber content, as also chewing activity, which is likely due to greater variation of NDF content at analyzed silages, and relatively small interval of variation of silages' average particle size. 


\title{
Acknowledgment
}

This study is realized by financial support of Ministry of Education and Science, Republic of Serbia, through the Project for technological development TR-31086.

\section{Uticaj stepena usitnjenosti kabastih hraniva i kompletnog obroka za krave u laktaciji na fizičku efektivnost i aktivnost žvakanja}

\author{
B. Stojanović, G. Grubić, N. Đorđević, A. Božičković, A. Ivetić
}

\section{Rezime}

U istraživanju je determinisan uticaj četiri različita stepena usitnjenosti silaže cele biljke kukuruza, senaže lucerke i kompletno mešanog obroka za krave u laktaciji, na fizičku efektivnost (pef), sadržaj fizički efektivnih vlakana (peNDF), i ukupnu aktivnost žvakanja. Utvrđena je visoka povezanost stepena usitnjenosti kabastih hraniva i kompletnog obroka sa njihovom fizičkom efektivnošću u ishrani krava, kao i sa sadržajem fizički efektivnih vlakana. Ustanovljen je statistički značajan efekat stepena usitnjenosti obroka na stimulisanje ukupne aktivnosti žvakanja kod krava u laktaciji.

\section{References}

BALCH C.C. (1971): Proposal to use time spent chewing as an index of the extent to which diets for ruminants possess the physical property of fibrousness characteristics of roughages. Br. J. Nutr., 26, 383.

HEINRICHS J., KONONOFF P. (2002): Evaluating particle size of forages and TMRs using the new Penn State Forage Particle Separator. http://www.das.psu.edu/dairy/nutrition/pdf/evaluating-particle-size-of-forages.pdf. KONONOFF P.J., HEINRICHS A.J., BUCKMASTER D.R. (2003): Modification of the Penn State forage and total mixed ration particle separator and the effects of moisture content on its measurement. J. Dairy Sci., 86, 1858-1863.

KONONOFF P.J., HEINRICHS A.J. (2003): The effect of reducing alfalfa haylage particle size on cows in early lactation. J. Dairy Sci., 86, 1445-1457.

KRAUSE K.M, COMBS D.K. (2003): Effects of forage particle size, forage source, and grain fermentability on performance and ruminal $\mathrm{pH}$ in midlactation cows. J. Dairy Sci., 86, 1382-1397. 
MERTENS D.R. (1997): Creating a system for meeting the fiber requirements of dairy cattle. J. Dairy Sci., 80, 1463-1482.

STATSOFT INC. (2003): STATISTICA (data analysis software system), version 6. www.statsoft.com.

STOJANOVIĆ B., GRUBIĆ G., ĐORĐEVIĆ N, BOŽIČKOVIĆ A., IVETIĆ A. (2009): Chemical and physical quality of forages for dairy cows nutrition. 13. International Symposium Feed Technology, 29.09-1.10.2009., Novi Sad. Proceedings, 217-228, 2009.

STOJANOVIĆ B., GRUBIĆ G., ĐORĐEVIĆ N., BOŽIČKOVIĆ A. (2008): Stepen usitnjenosti senaže lucerke u kompletnom obroku za krave u laktaciji. Biotechnology in Animal Husbandry, 24, spec. issue, 423-433.

STOJANOVIĆ B., GRUBIĆ G., ĐORĐEVIĆ N. (2002): Hranidbene karakteristike vlakana u obrocima za krave. Biotechnology in Animal Husbandry, 18, 5-6, 221-229.

SUDWEEKS E.M., ELY L.O., MERTENS D.R., SISK L.R. (1981): Assessing minimum amounts and form of roughages in ruminant diets: roughage value index system. J. Anim. Sci., 53, 1406.

YANG W.Z., BEAUCHEMIN K.A. (2007): Altering physically effective fiber intake through forage proportion and particle length: digestion and milk production. J. Dairy Sci., 90, 3410-3421.

YANG W.Z., BEAUCHEMIN K.A. (2006): Physically effective fiber: Method of determination and effects on chewing, ruminal acidosis, and digestion by dairy cows. J. Dairy Sci., 89, 2618-2633.

ZEBELI Q., TAFAJ M., STEINGASS H., METZLER B., DROCHNER W. (2006): Effects of physically effective fiber on digestive processes and milk fat content in early lactating dairy cows fed total mixed rations. J. Dairy Sci., 89, 651-668. 